\title{
Heroes of the Engram
}

\author{
Sheena A. Josselyn, ${ }^{1,2,3,4,5}$ @Stefan Köhler, ${ }^{6,7}$ and Paul W. Frankland ${ }^{1,2,3,4,5}$ \\ ${ }^{1}$ Program in Neurosciences and Mental Health, Hospital for Sick Children, Toronto, Ontario M5G 1X8, Canada, ${ }^{2}$ Department of Psychology, University of \\ Toronto, Toronto, Ontario M5S 3GM, Canada, ${ }^{3}$ Department of Physiology, University of Toronto, Toronto, Ontario M5S 1A8, Canada, ${ }^{4}$ Institute of Medical \\ Science, University of Toronto, Toronto, Ontario M5S 1A8, Canada, ${ }^{5}$ Canadian Institute for Advanced Research (CIFAR), Toronto, Ontario M5S 1A8, \\ Canada, ${ }^{6}$ Brain and Mind Institute and Department of Psychology, University of Western Ontario, London, Ontario N6A 5B7, Canada, and ${ }^{7}$ Rotman \\ Research Institute, Baycrest Centre, Toronto, Ontario, Ontario M6A 2E1, Canada
}

In 1904, Richard Semon introduced the term "engram" to describe the neural substrate responsible for (or at least important in) storing and recalling memories (i.e., a memory trace). The recent introduction of a vast array of powerful new tools to probe and manipulate memory function at the cell and neuronal circuit level has spurred an explosion of interest in studying the engram. However, the present "engram renaissance" was not borne in isolation but rather builds on a long tradition of memory research. We believe it is important to acknowledge the debts our current generation of scientists owes to those scientists who have offered key ideas, persevered through failed experiments and made important discoveries before us. Examining the past can also offer a fresh perspective on the present state and future promise of the field. Given the large amount of empirical advances made in recent years, it seems particularly timely to look back and review the scientists who introduced the seminal terminology, concepts, methodological approaches, and initial data pertaining to engrams. Rather than simply list their many accomplishments, here we color in some details of the lives and milestone contributions of our seven personal heroes of the engram (Richard Semon, Karl Lashley, Donald Hebb, Wilder Penfield, Brenda Milner, James McConnell, and Richard Thompson). In reviewing their historic role, we also illustrate how their work remains relevant to today's studies.

\section{Introduction}

In science, progress is achieved by building on the discoveries and theories of those who have gone before. John of Salisbury, a 12th Century theologian and author, was among the first to articulate this notion: "We are like dwarfs sitting on the shoulders of giants. We see more, and things that are more distant, than they did, not because our sight is superior or because we are taller than they, but because they raise us up, and by their great stature add to ours" (McGarry, 2009).

The sentiment that scientific knowledge is cumulative continues today. At a recent meeting, one of us (S.A.J.) overheard a current scientific leader paraphrase this idea remarking "if you think your idea is novel, it just means you haven't done your reading." The achievements of today's researchers simply would not be possible without the exciting discoveries (and disappointing experimental failures) of scientific endeavors in bygone days. We (the authors) study the neural basis of memory and believe it important to acknowledge the debts we owe to those scientists who offered speculations and probed mechanisms before us. Rather than reiterating a textbook list of their many accomplish-

Received Jan. 20, 2017; revised March 2, 2017; accepted March 16, 2017.

This work was supported by Canadian Institutes of Health Research Grant FDN-143227 to P.W.F., Grant MOP74650 to S.A.J., and Grant FRN-148839 to S.K. We thank Steve Maren, Richard Brown, and Larry Stern for helpful comments and discussion.

The authors declare no competing financial interests.

Correspondence should be addressed to Dr. Paul W. Frankland or Dr. Sheena A. Josselyn, Program in Neurosciences and Mental Health, Hospital for Sick Children, Toronto, Ontario M5G 1X8, Canada; or Dr. Stefan Köhler, The Brain and Mind Institute, Natural Sciences Building, Western University, London, Ontario N6A 5B7, Canada. E-mail: paul.frankland@sickkids.ca, sheena.josselyn@sickkids.ca, or stefank@uwo.ca.

DOI:10.1523/JNEUROSCI.0056-17.2017

Copyright $\odot 2017$ the authors $\quad 0270-6474 / 17 / 374647-11 \$ 15.00 / 0$ ments, though, we attempt to bring these scientific giants to life by coloring in the details of the lives and scientific contributions of our "heroes of the engram."

Of course, our list of heroes is necessarily nonexhaustive and entirely personal. Many contemporary scientists continue to offer remarkable insights into memory mechanisms, and we find these researchers and their discoveries inspiring. However, here we focus on predominantly historic figures. We trace the history of the "engram" and attempt to provide context to those who made key conceptual or empirical advances. Although each of our heroes made numerous contributions to our understanding of the engram and to other domains of neuroscience, we highlight the most pertinent and then elaborate on why we chose these particular individuals as heroes of the engram.

\section{The engram: defining the problem (or the problem defining)}

The engram may be defined as that entity that reflects the neural substrate of stored information resulting from past experience and bestowing upon organisms the ability to express memory in their behavior. The term "engram" was introduced by Richard Semon in 1904, although the concept of a physical memory trace likely originated in ancient Greece (Gomulicki, 1953). Semon defined an engram as "the enduring though primarily latent modification in the irritable substance produced by a stimulus" (Semon, 1921). By introducing a new term to describe a scientific entity, Semon attempted to circumvent potential confusion stemming from the use of vernacular terms in scientific memory research.

Scientists agree that most, if not all, animals possess the capacity to learn. This implies that a record or representation of the 

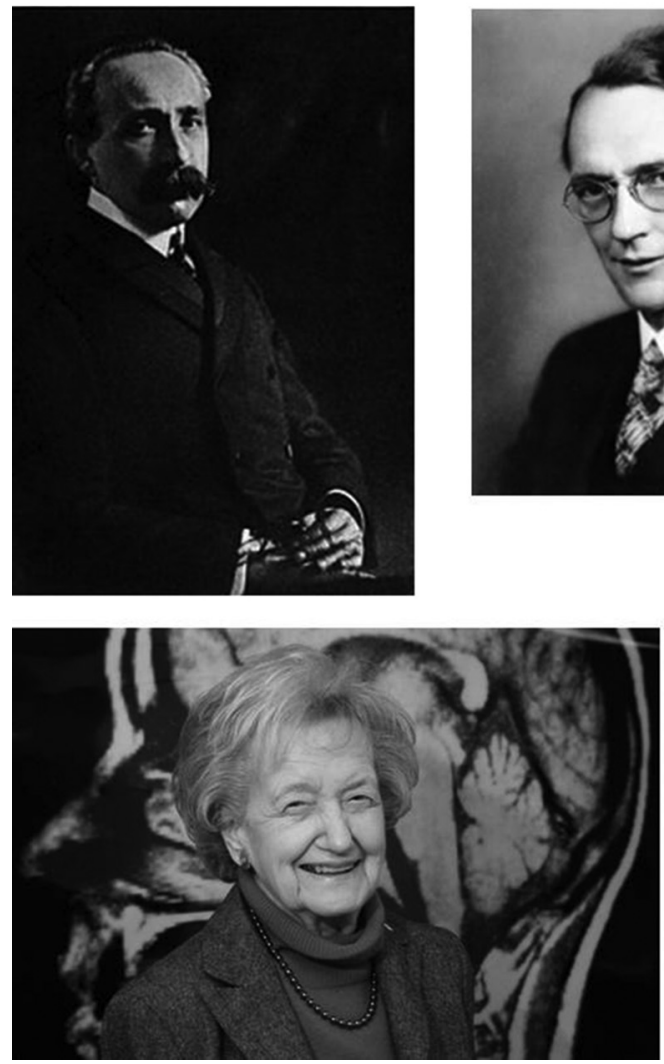
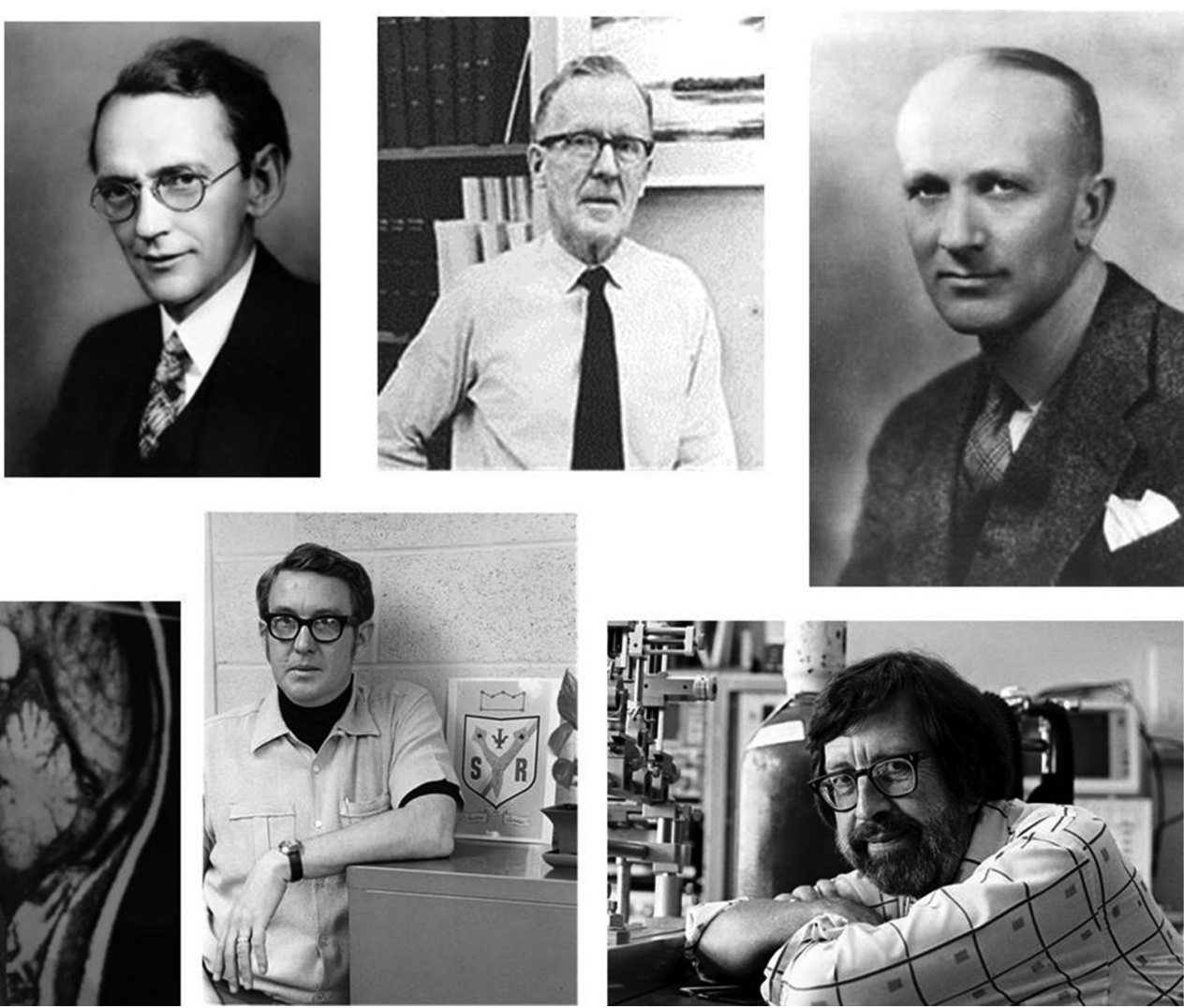

Figure 1. Images of our heroes of the engram. Left to right: Top, Richard Semon, Karl Lashley, Donald Hebb, Wilder Penfield. Bottom: Brenda Milner, James McConnell, Richard Thompson. Richard Semon: Picture in public domain due to its age. Karl Lashley: Reproduced with permission from the University of Chicago Photographic Archive (apf digital item number, e.g., apf1-03675), Special Collections Research Center, University of Chicago Library. Donald Hebb: Reproduced with permission from the McGill University Archive. Wilder Penfield: Reproduced with permission from the McGill University Archive. Brenda Milner: Reproduced courtesy of McGill University. James McConnell: Reproduced with permission from the Bentley Historical Library, University of Michigan. Richard Thompson: Reproduced with permission from the Society for Neuroscience.

learning outcome must be stored within the nervous system for later use, which points to the necessary existence of some form of an engram. However, this initial agreement likely marks the end of scientific consensus on the engram. The form, location, and precise definition of an engram continue to be widely debated (Poo et al., 2016). The use of the term "engram" goes in and out of scientific fashion. Currently, we are experiencing somewhat of an "engram renaissance," spurred by the development of molecular and circuit tools to probe and precisely manipulate brain function. These technical advances allow today's scientists to resurrect and test old, previously abandoned scientific questions to find new answers (Josselyn, 2010, 2015; Sakaguchi and Hayashi, 2012; Mayford, 2014; Tonegawa et al., 2015a, b; Eichenbaum, 2016; Kim et al., 2016; Poo et al., 2016).

\section{Semon, the overlooked hero who introduced the term "engram"}

Richard Wolfgang Semon (1859-1918) was an evolutionary zoologist who, despite leading a troubled life, proposed several prescient theories on memory (Fig. 1) (Schacter et al., 1978; Schacter, 2001). Semon received an MD (1886) and a PhD (Zoology, 1883) from the University of Jena working with Ernst Haeckel (who coined the phrase "ontogeny recapitulates phylogeny"). After completing his doctoral thesis (examining ontogeny of starfish and sea snails), he rose to the level of Associate Professor at Jena. By several accounts, Semon was an accomplished zoologist; a species of lizard, the green-blooded skink, Prasinohaema semoni, bears his name (Beolens et al., 2011). In the tradi- tion of one of his own scientific heroes, Charles Darwin, Semon led a biological expedition to Australia (where his team discovered 207 new species). However, a scandalous affair with the wife of a colleague (Maria Krehl, who was then married to Ludolph Krehl, an eminent professor at Jena) abruptly interrupted Semon's career. Semon resigned his position. He and Maria moved to Munich and were married. Semon became a Privatgelehrter (private scholar) without university affiliation. Because of this change in circumstance, Semon switched fields and began theorizing about memory (Schacter, 2001).

Semon published two monographs on memory: Die Mneme, 1904 [translated into English as The Mneme in 1921 (Semon, 1921)] and Die Mnemischen Empfindungen, 1909 [Mnemonic psychology (Semon, 1923)]. Perhaps inspired by Haeckel, in addition to introducing a conceptual framework of memory, Die Mneme also proposed a broader unifying theory highlighting the similarities between memory and inheritance. Learning acquired by a parent, Semon proposed, could be passed to future generations. Such a "soft inheritance" view was originally championed by the French biologist Jean Baptiste Pierre Antoine de Monet, Chevalier de Lamarck (often referred to simply as Lamarck) (1744-1829). By the time Die mneme was published, Lamarckian inheritance had been dismissed by the scientific community (Forsdyke, 2006), as was Semon's monograph.

As poignantly chronicled by Daniel Schacter, James Eich, and Endel Tulving (Schacter et al., 1978; Schacter, 2001), Semon's innovative ideas about memory were largely ignored at the time. The lack of attention and scientific acceptance affected Semon 
deeply (Schacter, 2001). In the spring of 1918, Maria died of cancer. On December 27 of that year, Semon shot himself through the heart, draped in a German flag while lying on Maria's bed. He was 59 years old.

Semon's contributions to the engram. Semon is best known for introducing two terms that endure in the lexicon of memory research today: "engram" and "ecphory." An engram (roughly corresponding to "memory trace") refers to the lasting physical changes in brain state and structure that occur in response to an event or experience. Once formed, an engram becomes dormant but may be awakened by presentation of parts of the original (or a similar) event, in a process Semon defined as ecphory (roughly corresponding to "memory retrieval").

In addition to developing new terminology, Semon strikingly foreshadowed modern-day memory concepts. In stark contrast to his contemporaries, who focused almost exclusively on learning, Semon also emphasized the relevance of retrieval. Within his framework, memory emerges as an interaction between a stored engram and retrieval cues. Moreover, Semon proposed that an engram-awakening stimulus need not completely overlap with the original stimulus. That an incomplete or partial retrieval cue is sufficient to induce memory retrieval anticipates the current concept of pattern completion (e.g., Neunuebel and Knierim, 2014).

In addition, Semon articulated ideas that may be interpreted as precursors of "multiple trace theory" (e.g., Nadel and Moscovitch, 1997). After learning, Semon proposed, cuing (i.e., awakening) of the original engram would also lead to the generation of a new engram for this event. The old (retrieved) and new engrams became associated by contiguity, thereby strengthening the original memory (with the interplay between engrams described as homophony). The simultaneous retrieval of multiple engrams with similar content and their subsequent association (the "resonance between engrams") could provide a basis for complex cognitive processes, such as generalization, abstraction, and knowledge formation (e.g., McClelland et al., 1995). Therefore, Semon was one of the first to emphasize that the representation of an event (an engram) is not static but changes with use.

Although reticent to speculate on the precise nature of an engram [("To follow this into the molecular field seems to me ... a hopeless undertaking at the present stage of our knowledge; and for my part I renounce the task" (Semon, 1923, p 154)], Semon hypothesized that an engram is not strictly localized to one particular cell or brain region (wherein one cell would represent one engram), but rather an engram is more distributed. When criticized for not being sufficiently precise in his definition of an engram, Semon countered: "I should be as able as anyone else to turn out some sort of schematic representation on the model of the diagram . . . in which engrams would be naively represented, schematized as tiny particles and conveniently packed together. This would meet the views of those readers whose thirst for causality requires such schematic representation, and who cannot resign themselves to leaving such questions open for the time being" (Semon, 1923, p 329).

Even though the philosopher Bertrand Russell partly based his book Analysis of mind (Russell, 1922) on Semon's creative ideas, Semon's theories were ignored by memory researchers during his life and well after his death. Indeed, he remained largely unknown until Schacter and colleagues revealed the Stranger behind the engram (Schacter et al., 1978; Schacter, 1982, 2001). Around this time, Tulving also introduced the concept of "synergistic ecphory" to describe the process by which retrieval cues interact with stored information to allow for the conscious recovery of past experiences and events (Tulving, 1982).

Why were Semon's ideas ignored? Reasons likely include his controversial Lamarckian views, the dominance of simple association memory models, and the absence of experimental data. In addition, Semon was not associated with a prestigious university or integrated into the memory research community. Indeed, Schacter (1982) speculates that the so-called Matthew effect may have adversely impacted Semon's (as well as other scientists') career.

The Matthew effect, a phrase coined by Robert Merton (Merton, 1968), is based on a quote attributed to the apostle: "For unto every one that hath shall be given, and he shall have abundance: but from him that hath not shall be taken even that which he hath." - Matthew 25:29, King James Version.

In science, the Matthew effect describes the phenomenon whereby the work of high-status scientists receives greater attention than equivalent work by lesser-known scientists ("the rich get richer while the poor get poorer," the "rich club" or accumulative advantage). Semon was the ultimate outsider in terms of university affiliation, "scientific pedigree," and links to the memory research community. Semon's sad biography illustrates the negative consequences (both personal and to overall scientific progress) of ignoring views outside typical scientific precincts (based on geography, methodology, gender, ethnicity, or scientific pedigree).

Why is Semon a hero of the engram? We admire his creative, forward-thinking ideas and find it frankly eerie how he anticipated many current memory concepts. Semon not only introduced useful memory terminology, but also a conceptual framework of how information is represented in the brain over time. He reminds us of the importance of theory in science. Leonardo da Vinci aptly wrote: "[S]He who loves practice without theory is like the sailor who boards ship without a rudder and compass and never knows where [s] he may cast."

Semon's notion of an engram was of a sufficient theoretical depth that it was foundational for developing criteria we recently used to evaluate whether today's researchers have indeed "found the engram” (Josselyn et al., 2015). Finally, even Semon's controversial idea regarding the inheritance of acquired experience has become more broadly accepted and nowadays is an active area of study (Gräff and Mansuy, 2008; Dias and Ressler, 2014). Therefore, Semon is our founding hero of the engram. He is, however, a tragic hero.

\section{Lashley, the quixotic hero who searched for "engram"}

Semon introduced the term "engram." However, the American scientist, Karl Spencer Lashley (1890-1958) popularized the term (Fig. 1) (Bruce, 1998). After graduating high school at the age of 14, Lashley initially studied English at college, but soon switched to zoology. Although his PhD was in Genetics (Johns Hopkins, 1911), his career was shaped by two scientists from other disciplines (Bartlett, 1960; Beach, 1961). First, while a student, Lashley volunteered in John B. Watson's (the founder of behaviorism) laboratory. Second, Lashley collaborated with Shepherd Franz (who was among the first to examine the functional impact of brain injury in humans and pioneered the use of brain lesions to study behavior in experimental animals). Indeed, Franz taught Lashley the ablation technique, which became Lashley's primary tool in his hunt for the engram (Franz and Lashley, 1917).

Lashley's contributions to the engram. For $>30$ years, Lashley searched in the brain (predominantly, the cortex) for an engram. In a typical experiment, he trained rats to navigate a maze for 
food before ablating different parts of the cortex. The logic underlying these experiments was simple; if the ablated cortex contained the engram supporting the memory for maze learning, then rats would show a memory deficit upon testing. Although the experimental details varied, the results from many experiments were largely consistent: the size, but importantly not the location, of lesion correlated with the magnitude of memory disruption. Lashley concluded that the engram supporting this type of memory was not localized to a discrete cortical region. The engram, it seemed, was everywhere, but in no one place specifically. Lashley once quipped "the trick, is not to find where the trace is located, but where it is not" (Orbach, 1999). Lashley's conclusion that memory (and other cognitive functions) is not localized to a particular brain area gained widespread acceptance. Indeed, Franz published a paper in Science mocking "localizationists" entitled the "New Phrenology" (Franz, 1912).

Why is Lashley a hero of the engram? Lashley failed to find his engram. Nonetheless, he provided meaningful conceptual and methodological contributions to our understanding of an engram that we feel elevate him to hero status. Lashley's conclusions that memory (and other brain functions) is not localized to a single brain region resonate with modern concepts of distributed processing. That is, behavior emerges from the concerted action of many brain regions (rather than a single brain area in isolation). Distributed processing is foundational for much of today's human neuroimaging research on memory and beyond (McIntosh, 1999; Friston, 2002). Human brain networks have been identified pertaining to learning, consolidation, and retrieval (Kim, 2011; Rugg and Vilberg, 2013; Moscovitch et al., 2016). These network-based approaches are also gaining traction in rodents (Wheeler et al., 2013), where, somewhat ironically, much of the research since Lashley has focused on single brain areas.

Science progresses not only by advancing theories, but also by developing and applying new techniques. Lashley pioneered the systematic use of brain lesions to study memory in experimental animals. Although his thermocautery lesions were novel at the time, they are blunt by today's standards and produced unintended collateral damage. Nowadays, to circumvent these offtarget effects, "tagging" strategies have been developed that specifically target distributed neuronal ensembles active at the time of memory encoding (sometimes referred to as "engram cells"). Silencing these "engram ensembles" (but not random cells) in a recall test impairs memory retrieval (Garner et al., 2012; Liu et al., 2012; Denny et al., 2014; Hsiang et al., 2014; Nonaka et al., 2014; Tanaka et al., 2014; Ramirez et al., 2015; Ryan et al., 2015; Berndt et al., 2016; Li et al., 2016; Park et al., 2016; Rashid et al., 2016; Roy et al., 2016; Yoshii et al., 2016). In this way, many current researchers are probing engrams with more refined variants of methods introduced by Lashley.

We admire Lashley for his scientific stamina and dogged pursuit (over decades!) of a single, important question. We tip our respective hats to the poetic chronicling of his scientific journey. In one of his final public addresses in 1957, Lashley compared his pursuit of the engram to a similar quest portrayed in Lewis Carroll's poem "The hunting of a Snark" (Orbach, 1998). To Lashley, the Snark, a mythical creature that evades capture despite valiant effort, became a regrettable metaphor for his engram.

We wonder, though, whether Lashley nearly caught his elusive Snark. Peter Milner, a student of Donald Hebb's and one of the codiscoverers of rewarding brain stimulation (Olds and Milner, 1954), offered an interesting perspective of Lashley's data (Milner, 1999): “. . I had another look at this seventy year old classic [referring to Lashley's papers]. Cortical lesions for the research were almost all produced by thermocautery, whose effects are not easy to predict. Fortunately Lashley made careful measurements of the extent of damage, including unintended subcortical lesions. In the rat the hippocampus lies closely below a considerable part of the posterior cortex, so it is not surprising that it bore the brunt of the unintended damage. Of the 37 experimental subjects in the study, 21 also sustained hippocampal lesions. Again, it is not surprising that the frequency and extent of these lesions appears to be highly correlated with the size of the corresponding cortical lesions. Lashley, not having the benefit of subsequent findings on the dire effect of hippocampal lesions on maze learning, chose to ignore this damage (along with damage to the thalamus, striatum, and other subcortical structures). Considering that blindness did not prevent normal learning of the mazes, it is entirely possible that the hippocampal lesions were a major cause of the maze deficits seen by Lashley. Perhaps Lashley just missed finding his elusive engram-in the hippocampus."

Frank Beach, a student of Lashley's and one of the founders of behavioral endocrinology, characterized his mentor, as an "eminent psychologist with no earned degree in psychology, famous theorist who specialized in disproving theories, including his own, and inspiring teacher who described all teaching as useless" (Beach, 1961). Despite having completed no formal course in psychology, Lashley was voted American Psychological Association president in 1929 !

Finally, it is also noteworthy that Lashley was aware of Semon's work (citing Semon on two occasions) (Lashley, 1933, 1935), although Lashley failed to attribute the term "engram" to Semon. It is interesting, then, that Lashley characterized his own experiments as searching for the "engram," rather than searching for the more common "memory trace." That he chose the term "engram" suggests Lashley was attributing the notion that an engram is stable (and therefore localizable) to Semon. This is curious because Semon emphasized the dynamic nature of memory representations and the importance of retrieval (ecphory).

\section{Hebb, the hero who wrote the book on cell assemblies and proposed biological mechanisms underlying the engram}

Donald Olding Hebb (1904-1985) was a student of Lashley's. He was born in Nova Scotia, Canada (Fig. 1) (Brown and Milner, 2003; Cooper, 2005; Brown, 2006). Both Hebb's parents were medical doctors; his mother, Mary Clara Olding, was only the third woman to earn a medical degree in Nova Scotia. Hebb completed an undergraduate degree in English and Philosophy with the goal of becoming a novelist (Milner and Milner, 1996). After working as a teacher, on a farm and as a day-laborer, he completed an MA in Psychology (McGill University, 1932). For his $\mathrm{PhD}$ (with Lashley), Hebb examined vision in dark-reared rats (Harvard, 1936). Hebb returned to Montreal to work with Wilder Penfield at the Montreal Neurological Institute (MNI) where he examined the impact of human brain injury on intelligence. He questioned the utility of standardized IQ tests in this regard and, together with N. W. Morton, developed improved instruments [McGill Picture Anomaly Test and Adult Comprehension Test (Hebb and Morton, 1943)]. During his short time at Queen's University at Kingston, Ontario, Hebb and Kenneth Williams devised a new maze to assess memory in rodents (the Hebb-Williams maze) (Hebb and Williams, 1946). Using this maze, Hebb showed the lasting influence of early-life experience on cognition, a finding that further strengthened his belief in the importance of early education.

In 1942, Hebb again joined Lashley (now at Yerkes Laboratories of Primate Biology) as a research fellow. In addition to con- 
ducting experiments, Hebb completed much of the manuscript for The organization of behavior: a neuropsychological theory, his landmark book. Hebb invited Lashley to be a coauthor, but Lashley declined (Brown, 2006). Indeed, by many accounts, Hebb and Lashley enjoyed a challenging relationship. According to Jack Orbach (Lashley's last postdoctoral fellow), Hebb shared initial drafts of his book with Lashley who commented on some chapters (Orbach, 1998). Hebb did not incorporate these suggestions into the final manuscript (Orbach, 1998). Lashley never cited this book in writing but did mention it in one of his final lectures (Orbach, 1999).

The organization of behavior was initially rejected by Charles C. Thomas Publishers before being published in 1949 by John Wiley \& Sons, to widespread acclaim. It continues to be regarded as one of the most influential books in neuroscience. Hebb's goal was to generate a "general theory of behavior that attempts to bridge the gap between neurophysiology and psychology" (Hebb, 1949 , p vii). While working with Penfield, Hebb noted that destruction of large amounts of cortex in humans produced little effect on memory (Hebb and Penfield, 1940; Hebb, 1945), a finding that parallels many of Lashley's results. These, and many others results, provided the foundation for Hebb's cell assembly theory in which he proposed a widely distributed neural substrate for memory.

Hebb's contributions to the engram. Hebb defined a cell assembly as a group of reciprocally interconnected cells that are simultaneously active during an event. Because these cells are interconnected, activity within the network is maintained briefly after the event (allowing the event to be represented in short-term memory). Recurrent activity of sufficient duration within the cell assembly induces growth or metabolic change that strengthens the interconnections between assembly cells (neurons that fire together wire together), allowing the event to be represented in longer-term memory. Because the cell assembly is highly interconnected, the entire assembly may be activated if only a subset of cells is activated, by a process of pattern completion that induces memory retrieval. As Hebb's cell assembly could be widely distributed within and across brain regions, destruction of a small component would not lead to catastrophic network failure (referred to as graceful degradation in connectionist and neural network fields), perhaps accounting for the futility of Lashley's search.

Why is Hebb a hero of the engram? Hebb is one of our heroes because he was one of the first to articulate a clear mechanistic vision of how an engram (or cell assembly) is formed. Hebb proposed that synaptic strengthening between groups of neurons that are active during an event (corresponding to engram formation) provides the basis for longer-term memory and that recapitulation of this ensemble activity provides the basis for remembering. His theory straddled multiple spatial scales, integrating synaptic strengthening (a microscale phenomenon) with cell assembly formation (a mesoscale phenomenon). Curiously, these mechanistic insights were not born out of empirical findings as crucial supporting evidence (e.g., LTP, spike-timingdependent synaptic plasticity, and cell assemblies) would emerge only decades later (e.g., Bliss and Lomo, 1973; Wilson and McNaughton, 1994; Bi and Poo, 1998; Carrillo-Reid et al., 2016). Contemporary engram studies are guided, almost without exception, by Hebb's concept of a cell assembly.

Hebb's goal was to link the brain with behavior through a novel interdisciplinary approach. By "physiologizing" psychology and psychiatry, he spawned the new subdisciplines of physiological psychology and behavioral neuroscience. His cell assembly theory and learning algorithm for adjusting the weights between connected cells helped give rise to the field of artificial networks. That The organization of behavior continues to be read and frequently quoted is testament to Hebb's enduring influence. It is not often that a scientist's name becomes an adjective (Hebbian plasticity, Hebbian synapse).

\section{Penfield, the hero who artificially awakened an engram}

Semon defined ecphory as the activation of a latent engram by an external cue. However, it was Wilder Graves Penfield (18911976) who first discovered that focal electrical stimulation alone may artificially awaken an engram in humans (Fig. 1).

Penfield was born in Spokane, Washington and received an undergraduate degree in Literature (Princeton, 1913). He was a Rhodes Scholar and studied Physiology at Oxford. Here, he met Charles Sherrington, whom Penfield credits with inspiring his mission to understand the mind. After receiving his MD (Johns Hopkins, 1918), Penfield worked at several institutions, before moving to McGill University where he helped create the MNI. Penfield remained MNI director until 1960. Following his retirement, he was a policy advocate and prolific author (publishing novels, autobiographies, and collections of essays) (Penfield, 1977; Lewis, 1981). His final book was completed 3 weeks before his death.

Penfield was a neurosurgeon who treated patients with intractable epilepsy by surgically resecting tissue that harbored the seizure focus. Similar to many scientists, Penfield's professional life was influenced by his personal life. Penfield's sister, Ruth Inglis, suffered from seizures for many years. After being diagnosed with a malignant brain tumor in her right frontal lobe, Penfield performed the surgery to remove it. As is common with this type of surgery, Penfield's patient (and sister) remained awake (and talking) during the operation. The tumor was larger than anticipated, prompting Penfield to remove almost the entire right frontal lobe. The operation successfully removed much of the tumor but left Inglis with difficulties in planning and organization (consistent with a dysexecutive syndrome). Inglis' cancer returned and she died 2 years later. Penfield reported the results of his surgery (including results at autopsy) as a case report (Penfield and Evans, 1935).

Penfield's contributions to the engram. Penfield's primary goal was not to study engrams. However, to localize the source of focal epileptic seizures, he functionally mapped local brain topography in awake patients by electrically stimulating different brain surface regions. Stimulation that elicited motor responses (such as finger movement) confirmed the positioning of the electrode in the motor cortex, in an approach that ultimately defined the motor and sensory homunculus (Penfield and Boldfrey, 1937).

In some cases, stimulating the lateral superior temporal lobe triggered an "an experience which the patient could easily recognize and identify as having been part of a previous experience" (Penfield and Perot, 1963, p 672). Whether electrical stimulation of specific brain regions is sufficient to elicit veridical memory recall is controversial (Squire, 1987). However, some of Penfield's patients clearly reported experiential phenomena that seemed very memory-like. For instance, following stimulation, one patient (Case 3, RW) reported: "My mother is telling my brother he has got his coat on backwards. I can just hear them." When asked if this event actually occurred, RW reported, "Oh yes, just before I came here” (Penfield and Perot, 1963, p 611). Thus, Penfield's electric stimulation elicited experiences that, at minimum, had strong phenomenological resemblance to those that occur when external cues awaken engrams in natu- 
ral environments (for a contemporary example, see Hamani et al., 2008).

Why is Penfield a hero of the engram? Penfield is a hero for two primary reasons. First, his work anticipated (and inspired) the modern era of "engram awakening" experiments in rodents (e.g., Garner et al., 2012; Liu et al., 2012; Ramirez et al., 2013; Cowansage et al., 2014; Redondo et al., 2014; Yiu et al., 2014; Ramirez et al., 2015; Rogerson et al., 2016; Roy et al., 2016). These studies use optogenetics or chemogenetics to artificially reactivate neuronal populations that were active at the time of encoding. Their findings show that stimulation is sufficient to induce behavioral memory expression.

Second, Penfield's career illustrates the power of leveraging clinical techniques to address fundamental science questions. This tradition continues to flourish in present-day clinical neuroscience, including memory experiments conducted in epilepsy patients using intracranial electrocorticography. For instance, in one study, scientists were able to track a cell in the medial temporal lobe that was active both during encoding of an image of a famous actor (Tom Cruise) and during subsequent free recall of that actor's name (Gelbard-Sagiv et al., 2008).

Although Penfield did not intend to study engrams, his Gold Medal Lecture to the Royal Society of Medicine was entitled "Engrams in the human brain." In the accompanying article, he writes: "engrams' is a word psychologists use frequently although what they mean by it neither they nor the physiologists have, as yet, quite decided" (Penfield, 1968, p 831). Finally, Penfield is a hero because he paved the way for the important contributions of our next hero, Brenda Milner.

\section{Milner, the hero who localized an engram to the hippocampus}

Brenda Milner (1918-) was born in Manchester, England. She was a precocious reader and loved literature, math, and languages (Milner, 1998) (Fig. 1). Milner began her BA in Math but soon switched to Experimental Psychology (Cambridge, 1939). Her MA (Cambridge, 1949) was interrupted by the outbreak of WWII. Following the war, Milner moved with her husband (Peter Milner) to Canada, where she completed a PhD with Hebb (McGill University, 1952). Here, she was introduced to Penfield and began investigating the effects of temporal lobe removal on human cognition and behavior in the context of epilepsy surgery. After graduating, Milner remained at McGill University and the MNI, where to this day she continues to make crucial discoveries about the organization of memory and other cognitive functions in the human brain.

Milner's contributions to the engram. While working with Penfield, Milner tested two patients (PB and FC) who developed profound memory loss following unilateral temporal lobectomy. This finding was surprising as memory loss was not typically observed following unilateral resection. Milner and Penfield suspected that both patients had a "silent" lesion in the contralateral temporal lobe, a suspicion that was later supported (Penfield and Milner, 1958). Their results were reported at the American Neurological Association conference in 1955, where the American neurosurgeon William Scoville learned of their work. Milner was subsequently invited to study one of Scoville's patients who experienced memory loss following bilateral medial temporal lobe resection in an attempt to combat severe, drug-resistant epilepsy. This patient is now widely known to the research community as Henry Molaison (patient HM).

In a landmark paper (Scoville and Milner, 1957), Scoville and Milner assessed the cognitive outcomes (IQ and memory scores) of 10 patients who had undergone temporal lobe resection. By comparing the amount and location of tissue removed with the patients' memory scores, they concluded that the hippocampal region, including the hippocampus proper and adjacent temporal lobe structures, was critical for the formation of long-term memory.

Lashley's final public address in 1957 concluded that the engram was elusive. Yet at this time, Milner and colleagues presented evidence that a specific brain region, the medial temporal lobe, plays a unique and necessary role in memory functioning. Milner and colleagues' discoveries represented the most compelling evidence for localization of memory at the time and pioneered an entire field dedicated to understanding the role of the hippocampus in memory.

Why is Milner a hero of the engram? By merging neurology with experimental psychology, Milner originated the neuropsychological tradition that dominated human memory research over the next several decades. With the arrival of brain imaging and related techniques, this, in turn, evolved into the contemporary field of cognitive neuroscience. Using this neuropsychological approach, Milner made several critical discoveries into understanding memory.

First, Milner's work offered unique new evidence for localization of memory that guided a more targeted search for the engram in decades of neuroscience research. Second, her studies revealed that memory is not unitary. To fully interrogate the extent of HM's memory loss, Milner creatively applied neuropsychological tests and experimental procedures. For example, she observed that HM had no difficulties learning a mirror-drawing task over multiple trials despite being unable to recall any pertinent prior experience with the task (Milner, 1962). Therefore, Milner emphasized that an understanding of the role of specific brain structures in memory requires careful consideration of the type of memory probed. Moreover, her results provide the cornerstone for subsequent ideas of multiple memory systems (Moscovitch et al., 2005) and ushered in the modern era of systems memory research.

Third, Milner revealed evidence that speaks to the dynamic nature of memory. HM was able to remember information acquired long before the surgery, but not similar information acquired shortly before (i.e., memories that were $<3$ years old). The observation that retrograde loss following medial temporal lobe damage is temporally graded provides the foundation for contemporary views of systems consolidation (Frankland and Bontempi, 2005). Interestingly, while the majority of scientists likely associate HM's temporal gradient with the standard model of systems consolidation (e.g., Squire and Alvarez, 1995), even at the time of publication, Milner's views were considerably more nuanced (Moscovitch, 2012). In the standard consolidation model, memories for events are thought to initially depend on the medial temporal lobe for their expression. However, with time, they come to be represented in a distributed cortical network, and may be expressed independently of the hippocampus. Although this change in organization need not involve a change in memory quality in the standard model, Penfield and Milner (1958) proposed that, as memories become independent of the hippocampus, they lose episodic detail and become more generalized in nature.

This emphasis on memory quality anticipates multiple trace theory (Nadel and Moscovitch, 1997), and its derivative, transformation theory (Winocur et al., 2010). Indeed, similar to multiple trace and transformation theory, Penfield and Milner (1958) argued that the hippocampus was always necessary for detailed 


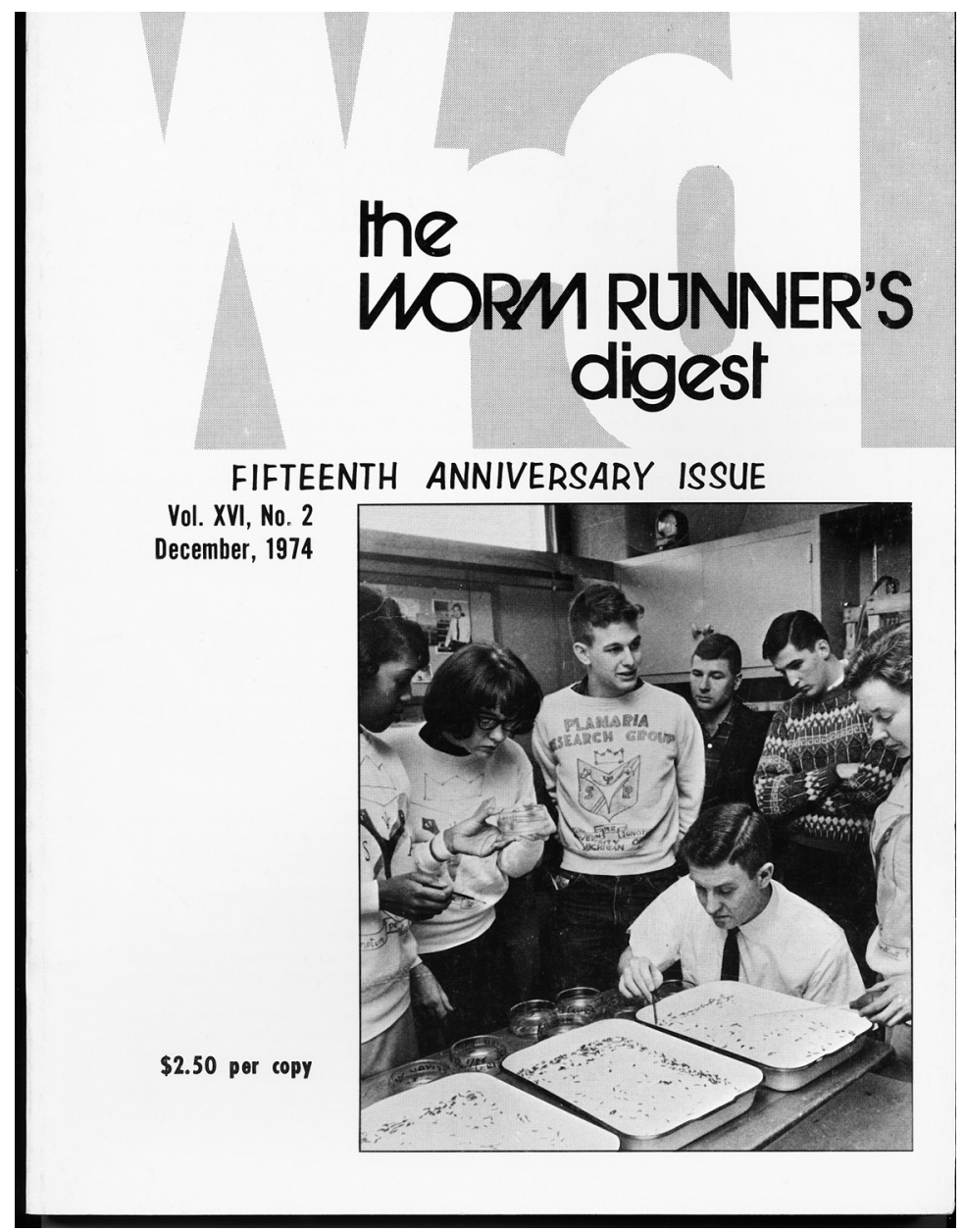

Figure 2. Images of copy of Worm Runner's Digest. Courtesy of Larry Stern, Professor of Sociology, Collin College (Plano, Texas).

ditioned contraction response (Thompson and McConnell, 1955). Taking advantage of the regenerative capacity of flatworms, he showed that each half of a trained-andthen-bisected flatworm became a new flatworm that retained some memory. That is, both the tail and head halves of the original flatworm showed savings when retrained. In a penultimate test of the hypothesis that the engram could be transmitted via RNA, McConnell mashed trained worms and fed them to naive worms. Naive worms showed behavioral savings as if the memory was transferred.

McConnell's memory transfer findings were published (McConnell et al., 1959; McConnell, 1962) and disseminated in the popular press (Time magazine wryly suggested an innovative use for old college professors). McConnell also self-published his findings in a scientific/ satirical journal entitled The Worm Runner's Digest (Fig. 2). This journal featured light-hearted contributions from noted researchers, including Harry Harlow ("Yearning and learning," a discussion of monkey reproduction) and B. F. Skinner (who contributed two parodies of behaviorism) as well as an article entitled "Learned helplessness in pet rocks (Roccus pettus)" (Stern, 2013).

Many attempted to replicate McConnell's memory transfer findings. Some replicated his findings, but many did not. McConnell's work was widely criticized for being poorly designed and poorly con-

recollection. They noted that voluntary detailed recollection was only possible for a short time after memory formation, but detailed memory might be accessible via electrical stimulation (evoking the "record of the stream of consciousness"), even at remote time points (Moscovitch, 2012).

\section{McConnell, a maverick engram hero in the spirit of Semon}

The history of the engram is an interesting story populated by pioneering, and sometimes colorful, scientists. One reason Semon's contributions may have been overlooked was his unpopular support of Lamarckian inheritance (Schacter, 2001). A resurgence of "soft inheritance" of memory was led by James Vernon McConnell (1925-1990) in the 1960s (Fig. 1). McConnell popularized the idea that the engram was encoded in RNA and could be transmitted to offspring. This theory derived from his famous (some would argue infamous) cannibalistic flatworm experiments (Stern, 2013).

McConnell received a $\mathrm{PhD}$ in Psychology (University of Texas, 1956). Shortly after graduating, he began a faculty position at the University of Michigan (Rilling, 1996). McConnell wrote several books and countless articles and had a wide range of scientific interests (from sensory processing in children with autism to the biological basis of learning).

McConnell's contributions to the engram. McConnell showed it was possible to classically condition planaria flatworms. He trained flatworms to form an association between a light and a shock. When reexposed to the light, the flatworms exhibited a con- trolled. He lost his scientific prestige and grants, although he continued to teach and write. In an interesting footnote, in 1985 McConnell was targeted by Theodore Kaczynski, the Unabomber, perhaps because of McConnell's notoriety in the popular press. McConnell suffered hearing loss when a letter bomb addressed to him exploded.

Why is McConnell a hero of the engram? While intergenerational memory inheritance was dismissed since Semon's time, similar ideas are now being pursued actively. A recent review asked "RNAi and brain function: was McConnell on the right track?" (Smalheiser et al., 2001). McConnell's finding that both halves of a trained, but bisected, flatworm showed memory was replicated using automated procedures (Shomrat and Levin, 2013). Finally, recent data suggest that critical components of an engram are localized in the nucleus of neurons, rather than at the synapse (Chen et al., 2014; Ryan et al., 2015). Such results are generally consistent with epigenetic studies suggesting that DNA modifications could be an important component of an engram relaying information to future generations (Gräff and Mansuy, 2008; Dias and Ressler, 2014). Once again, therefore, the story of the engram seems to be going full circle, back to Semon.

By showing that a "simple" invertebrate was capable of Pavlovian conditioning, McConnell made an important contribution that provided not only a simple behavioral model for studying the engram, but that was also of interest to the scientific community at large. Finally, we applaud McConnell's playful approach to science: "We've insisted that the [Worm Runner's] 
Digest be a mixture of fact and fun, for it seems to me that anyone who takes himself, or his work, too seriously is in a perilous state of mental health" (Stern, 2013).

Thompson, the hero who found an engram in the cerebellum Richard Frederick Thompson (1930-2014) grew up in Portland, Oregon (Fig. 1). As a child, he was a voracious reader, reading every book in the neighborhood library. During his undergraduate degree (Reed College, 1952), he experimentally tested one of Lashley's theories on visual discrimination in rats. Indeed, Thompson credits Lashley with his interest in psychology. Thompson completed his $\mathrm{PhD}$ and postdoctoral fellowship (Psychology, University of Wisconsin, 1956, 1959) with W. J. Brogden and Clinton Woolsey. Following this, Thompson held faculty positions at several institutions (including University of Oregon School of Medicine, University of California at Irvine, Stanford, Harvard, and University of Southern California). While at Harvard, Thompson was the first person to occupy Lashley's chair after his death. The influence of Lashley can be seen throughout Thompson's scientific career and his own search for an engram (Thompson, 1998).

Thompson's contributions to the engram. To search for his engram, Thompson used short delay eye-blink conditioning in rabbits. In this preparation, an auditory tone, the conditioned stimulus (CS) is paired with an aversive air puff to the cornea, the unconditioned stimulus (US). In naive rabbits, the CS elicits little behavioral response, whereas the US evokes blinking. Throughout the course of training, though, rabbits begin blinking during the CS, thereby anticipating US delivery.

Thompson defined two criteria that must be satisfied to conclude that a given brain region is critical to an engram (Steinmetz et al., 1992). First, neural recordings from the region must show learning-induced activity changes that correspond to the learned behavioral response. Second, destruction of the region must both prevent acquisition and abolish retention of the previously learned response without impairing the response itself.

The hippocampus was Thompson's initial target. Although hippocampal cells increased firing rate over training (Berger and Thompson, 1978; Berger et al., 1980), thereby fulfilling his first criterion, lesioning the hippocampus did not prevent learning or abolish performance in this task (Berger and Orr, 1983; Port et al., 1986; Solomon et al., 1986). However, the cerebellum fulfilled both criteria. First, some cells in the ipsilateral cerebellum specifically increased firing during the CS (predicting the conditioned response) (McCormick and Thompson, 1984). Second, unilateral surgical removal of cerebellar cortex and deep nuclei before training prevented ipsilateral eyeblink conditioning and abolished previously learned conditioned responding but, importantly, did not prevent conditioning to the contralateral eye (McCormick et al., 1981; Lincoln et al., 1982). Thompson and colleagues concluded that the engram was localized within the ipsilateral cerebellum in a paper entitled "The engram found? Role of the cerebellum in classical conditioning of nictitating membrane and eyelid responses" (McCormick et al., 1981). In essence, Thompson accomplished what had eluded Lashley-he found "an engram."

There are several interesting side notes to this discovery. First, serendipity (a bent electrode) may have aided this discovery (Lavond and Kanzawa, 2001). Second, consistent with the history of the engram, Thompsons' finding of an engram in the cerebellum was replicated and accepted by some scientists (e.g., Yeo et al., 1985) but rejected by others (Welsh and Harvey, 1991; Bloedel, 1993; Bower, 1997). Indeed, in an autobiographical review,
Thompson writes: "Our cerebellar discoveries were not met with unanimous acclaim. Indeed, several cerebellar physiologists, among others, not only did not believe our findings, but attacked us in every conceivable way, both legitimate and otherwiseanother lesson in the dark side of science" (Thompson, 1998, p 537).

Why is Thompson a hero of the engram? Thompson is one of our heroes because he not only showed that the cerebellum is capable of plasticity and makes important contributions to behavior (ideas that were highly novel at the time) but also because he found an engram resulting from a simple, but specific, type of learning (i.e., eyeblink conditioning).

Why did Thompson find the engram that eluded Lashley? At least two factors likely contributed. First, Thompson used a relatively simple learning paradigm. Unlike Lashley's more complex maze paradigm in which it is unclear precisely how a given rat solves the task and what information is stored, classical conditioning experiments allow the experimenter complete control of presentation of the CS and US such that the timing and content of learning can be more readily evaluated. Second, Thompson applied a complementary array of techniques (from electrophysiological recording to electrical and chemical permanent lesioning to pharmacological reversible lesioning) to probe an engram. Because each technique has its own limitations, the combination of several tools is powerful. Indeed, contemporary researchers continue to emulate Thompson's general experimental template. For instance, today's researchers often record from multiple cells in multiple brain regions using tetrode recordings or using optical imaging techniques and not only "turn off" but also "turn on" cells and circuits to examine engrams and memory functioning. Therefore, Thompson provided a valuable scientific recipe.

\section{Conclusions}

In conclusion, our heroes of the engram are diverse. All were (or continue to be) scientific leaders, yet some gained eminence only posthumously. Despite their many differences, some commonalities emerge. First, courage: our heroes all seemed unafraid to merge or change fields. They followed their instincts, proposed new ideas, introduced new tools, and often went against convention. Second, across their diverse contributions, our heroes remind us of the parallel importance of theory and empirical discovery in science.

Thompson ends his autobiographic chapter noting:

"I have been very gratified by the many honors and awards I have received. But in the end, I and most other scientists will be forgotten. The discoveries we have made will be listed in the textbooks as facts not associated with names, and this is as it should be. Unlike other approaches to knowledge, scientific knowledge is cumulative" (Thompson, 1998, p 543).

We agree that scientific knowledge is cumulative. However, we disagree that the people behind the science should be forgotten. Remembering and honoring these heroes motivates us. We gain strength and perspective by appreciating their struggles and perseverance that prepare us for the inevitable bumps in the scientific road ahead of us all. Our current generation of scientists has been passed the baton, and it is up to us not only to run with it, but also to glance backwards, to acknowledge the previous runners' efforts.

Here, we discussed our personal heroes of the engram. Our appraisal is, of course, subjective. We invite others to compose their own lists. We hope that, in so doing, it will facilitate an appreciation for the many benefits of exploring the history of science. 


\section{References}

Bartlett FC (1960) Karl Spencer Lashley, 1890-1958. Biographical Memoirs of Fellows of the Royal Society 5:107-118. CrossRef

Beach FA (1961) Karl Spencer Lashley. Washington, DC: National Academy of Sciences.

Beolens B, Watkins M, Grayson M (2011) The eponym dictionary of reptiles. Baltimore: Johns Hopkins UP.

Berger TW, Orr WB (1983) Hippocampectomy selectively disrupts discrimination reversal conditioning of the rabbit nictitating membrane response. Behav Brain Res 8:49-68. CrossRef Medline

Berger TW, Thompson RF (1978) Identification of pyramidal cells as the critical elements in hippocampal neuronal plasticity during learning. Proc Natl Acad Sci U S A 75:1572-1576. CrossRef Medline

Berger TW, Laham RI, Thompson RF (1980) Hippocampal unit-behavior correlations during classical conditioning. Brain Res 193:229-248. CrossRef Medline

Berndt A, Lee SY, Wietek J, Ramakrishnan C, Steinberg EE, Rashid AJ, Kim H, Park S, Santoro A, Frankland PW, Iyer SM, Pak S, Ährlund-Richter S, Delp SL, Malenka RC, Josselyn SA, Carlén M, Hegemann P, Deisseroth K (2016) Structural foundations of optogenetics: determinants of channelrhodopsin ion selectivity. Proc Natl Acad Sci U S A 113:822-829. CrossRef Medline

Bi GQ, Poo MM (1998) Synaptic modifications in cultured hippocampal neurons: dependence on spike timing, synaptic strength, and postsynaptic cell type. J Neurosci 18:10464-10472. Medline

Bliss TV, Lomo T (1973) Long-lasting potentiation of synaptic transmission in the dentate area of the anaesthetized rabbit following stimulation of the perforant path. J Physiol 232:331-356. CrossRef Medline

Bloedel JR (1993) 'Involvement in' versus 'storage of.' Trends Neurosci 16: 451-452; discussion 453-454. Medline

Bower JM (1997) Is the cerebellum sensory for motor's sake, or motor for sensory's sake: the view from the whiskers of a rat? Prog Brain Res 114: 463-496. CrossRef Medline

Brown RE (2006) The life and work of Donald Olding Hebb. Acta Neurol Taiwan 15:127-142. Medline

Brown RE, Milner PM (2003) The legacy of Donald O. Hebb: more than the Hebb synapse. Nat Rev Neurosci 4:1013-1019. CrossRef Medline

Bruce D (1998) The Lashley-Hull debate revisited. Hist Psychol 1:69-84. CrossRef Medline

Carrillo-Reid L, Yang W, Bando Y, Peterka DS, Yuste R (2016) Imprinting and recalling cortical ensembles. Science 353:691-694. CrossRef Medline

Chen S, Cai D, Pearce K, Sun PY, Roberts AC, Glanzman DL (2014) Reinstatement of long-term memory following erasure of its behavioral and synaptic expression in Aplysia. eLife 3:e03896. CrossRef Medline

Cooper SJ (2005) Donald O. Hebb's synapse and learning rule: a history and commentary. Neurosci Biobehav Rev 28:851-874. CrossRef Medline

Cowansage KK, Shuman T, Dillingham BC, Chang A, Golshani P, Mayford M (2014) Direct reactivation of a coherent neocortical memory of context. Neuron 84:432-441. CrossRef Medline

Denny CA, Kheirbek MA, Alba EL, Tanaka KF, Brachman RA, Laughman KB, Tomm NK, Turi GF, Losonczy A, Hen R (2014) Hippocampal memory traces are differentially modulated by experience, time, and adult neurogenesis. Neuron 83:189-201. CrossRef Medline

Dias BG, Ressler KJ (2014) Parental olfactory experience influences behavior and neural structure in subsequent generations. Nat Neurosci 17:8996. CrossRef Medline

Eichenbaum H (2016) Still searching for the engram. Learn Behav 44:209222. CrossRef Medline

Forsdyke DR (2006) Heredity as transmission of information: Butlerian 'Intelligent Design.' Centaurus 48:133-148. CrossRef

Frankland PW, Bontempi B (2005) The organization of recent and remote memories. Nat Rev Neurosci 6:119-130. CrossRef Medline

Franz SI (1912) New phrenology. Science 35:321-328. CrossRef Medline

Franz SI, Lashley KS (1917) The retention of habits by the rat after destruction of the frontal portion of the cerebrum. Psychobiology 1:3-18. CrossRef

Friston K (2002) Beyond phrenology: what can neuroimaging tell us about distributed circuitry? Annu Rev Neurosci 25:221-250. CrossRef Medline

Garner AR, Rowland DC, Hwang SY, Baumgaertel K, Roth BL, Kentros C, Mayford M (2012) Generation of a synthetic memory trace. Science 335: 1513-1516. CrossRef Medline

Gelbard-Sagiv H, Mukamel R, Harel M, Malach R, Fried I (2008) Internally generated reactivation of single neurons in human hippocampus during free recall. Science 322:96-101. CrossRef Medline

Gomulicki BR (1953) The development and present status of the trace theory of memory. Br J Psychol Monogr Suppl 29:1-94.

Gräff J, Mansuy IM (2008) Epigenetic codes in cognition and behaviour. Behav Brain Res 192:70-87. CrossRef Medline

Hamani C, Hodaie M, Chiang J, del Campo M, Andrade DM, Sherman D, Mirski M, Mello LE, Lozano AM (2008) Deep brain stimulation of the anterior nucleus of the thalamus: effects of electrical stimulation on pilocarpine-induced seizures and status epilepticus. Epilepsy Res 78:117123. CrossRef Medline

Hebb DO (1945) Man's frontal lobes: a critical review. Arch Neurol Psychiatry 54:10-24. CrossRef

Hebb DO (1949) The organization of behavior, a neuropsychological theory. New York: Wiley.

Hebb DO, Morton NW (1943) The McGill Adult Comprehension Examination: "Verbal situation" and "Picture Anomaly" Series. J Educ Psychol 34:16-25. CrossRef

Hebb DO, Penfield W (1940) Human behavior after extensive bilateral removal from the frontal lobes. Arch Neurol Psychiatry 42:421-438.

Hebb DO, Williams K (1946) A method of rating animal intelligence. J Gen Psychol 34:59-65. CrossRef Medline

Hsiang HL, Epp JR, van den Oever MC, Yan C, Rashid AJ, Insel N, Ye L, Niibori Y, Deisseroth K, Frankland PW, Josselyn SA (2014) Manipulating a "cocaine engram" in mice. J Neurosci 34:14115-14127. CrossRef Medline

Josselyn SA (2010) Continuing the search for the engram: examining the mechanism of fear memories. J Psychiatry Neurosci 35:221-228. CrossRef Medline

Josselyn SA, Köhler S, Frankland PW (2015) Finding the engram. Nat Rev Neurosci 16:521-534. CrossRef Medline

Kim H (2011) Neural activity that predicts subsequent memory and forgetting: a meta-analysis of 74 fMRI studies. Neuroimage 54:2446-2461. CrossRef Medline

Kim JI, Cho HY, Han JH, Kaang BK (2016) Which neurons will be the engram-activated neurons and/or more excitable neurons? Exp Neurobiol 25:55-63. CrossRef Medline

Lashley KS (1933) Integrative functions of the cerebral cortex. Physiol Rev $13: 1-42$.

Lashley KS (1935) Studies of cerebral function in learning: XI. The behavior of the rat in latch-box situations. Comp Psychol Monogr 11:5-42.

Lavond DG, Kanzawa SA (2001) Reflections on R. F. Thompson's discovery of the engram. Engram 1:6-14.

Lewis J (1981) Something hidden: a biography of Wilder Penfield. Toronto: Doubleday.

Li L, Sanchez CP, Slaughter BD, Zhao Y, Khan MR, Unruh JR, Rubinstein B, Si K (2016) A putative biochemical engram of long-term memory. Curr Biol 26:3143-3156. CrossRef Medline

Lincoln JS, McCormick DA, Thompson RF (1982) Ipsilateral cerebellar lesions prevent learning of the classically conditioned nictitating membrane/eyelid response. Brain Res 242:190-193. CrossRef Medline

Liu X, Ramirez S, Pang PT, Puryear CB, Govindarajan A, Deisseroth K, Tonegawa S (2012) Optogenetic stimulation of a hippocampal engram activates fear memory recall. Nature 484:381-385. CrossRef Medline

Mayford M (2014) The search for a hippocampal engram. Philos Trans R Soc Lond B Biol Sci 369:20130161. CrossRef Medline

McClelland JL, McNaughton BL, O'Reilly RC (1995) Why there are complementary learning systems in the hippocampus and neocortex: insights from the successes and failures of connectionist models of learning and memory. Psychol Rev 102:419-457. CrossRef Medline

McConnell JV (1962) Memory transfer through cannibalism in planarians. J Neuropsychiatry Suppl 3:42-48.

McConnell JV, Jacobson AL, Kimble DP (1959) The effects of regeneration upon retention of a conditioned response in the planarian. J Comp Physiol Psychol 52:1-5. CrossRef Medline

McCormick DA, Thompson RF (1984) Neuronal responses of the rabbit cerebellum during acquisition and performance of a classically conditioned nictitating membrane-eyelid response. J Neurosci 4:2811-2822. Medline

McCormick DA, Lavond DG, Clark GA, Kettner RE, Rising CE, Thompson RF (1981) The engram found? Role of the cerebellum in classical conditioning of nictitating membrane and eyelid responses. Bull Psychonom Soc 18:103-105. CrossRef 
McGarry DB (2009) The Metalogicon of John of Salisbury: a TwelfthCentury defense of the verbal and logical arts of the trivium. Berkeley: University of California.

McIntosh AR (1999) Mapping cognition to the brain through neural interactions. Memory 7:523-548. CrossRef Medline

Merton RK (1968) The Matthew effect in science: the reward and communication systems of science are considered. Science 159:56-63. CrossRef Medline

Milner B (1962) Les troubles de la memoire accompagnant des lesions hippocampiques bilaterales. In Physiologie de l'Hippocampe, ed Passouant P, pp 257-272. Paris: Centre National de la Recherche Scientifique (CNRS).

Milner B (1998) Brenda Milner. In: The History of Neuroscience in Autobiography (Squire LR, ed), pp 276-305. San Diego: Academic.

Milner PM (1999) Cell assemblies: Whose idea? In: Psycholoquy [online]. http://www.cogsci.ecs.soton.ac.uk/cgi/psyc/newpsy?10.053.

Milner PM, Milner B (1996) Donald O. Hebb. Biographical memoirs of Fellows of the Royal Society 42:192-204. CrossRef

Moscovitch M (2012) Memory before and after H.M.: an impressionistic historical perspective. In: Epilepsy and memory (Zeman A, Kapur N, Jones-Gotman M, eds), pp 19-50. Oxford: Oxford UP.

Moscovitch M, Rosenbaum RS, Gilboa A, Addis DR, Westmacott R, Grady C, McAndrews MP, Levine B, Black S, Winocur G, Nadel L (2005) Functional neuroanatomy of remote episodic, semantic and spatial memory: a unified account based on multiple trace theory. J Anat 207:35-66. CrossRef Medline

Moscovitch M, Cabeza R, Winocur G, Nadel L (2016) Episodic memory and beyond: the hippocampus and neocortex in transformation. Annu Rev Psychol 67:105-134. CrossRef Medline

Nadel L, Moscovitch M (1997) Memory consolidation, retrograde amnesia and the hippocampal complex. Curr Opin Neurobiol 7:217-227. CrossRef Medline

Neunuebel JP, Knierim JJ (2014) CA3 retrieves coherent representations from degraded input: direct evidence for CA3 pattern completion and dentate gyrus pattern separation. Neuron 81:416-427. CrossRef Medline

Nonaka A, Toyoda T, Miura Y, Hitora-Imamura N, Naka M, Eguchi M, Yamaguchi S, Ikegaya Y, Matsuki N, Nomura H (2014) Synaptic plasticity associated with a memory engram in the basolateral amygdala. J Neurosci 34:9305-9309. CrossRef Medline

Olds J, Milner P (1954) Positive reinforcement produced by electrical stimulation of septal area and other regions of rat brain. J Comp Physiol Psychol 47:419-427. CrossRef Medline

Orbach J (1998) The neuropsychological theories of Lashley and Hebb. Lanham, MD: University Press of America.

Orbach J (1999) The neuropsychological theories of Lashley and Hebb. http://www.cogsci.ecs.soton.ac.uk/cgi/psyc/newpsy?10.029.

Park S, Kramer EE, Mercaldo V, Rashid AJ, Insel N, Frankland PW, Josselyn SA (2016) Neuronal allocation to a hippocampal engram. Neuropsychopharmacology 41:2987-2993. CrossRef Medline

Penfield W (1968) Engrams in the human brain: mechanisms of memory. Proc R Soc Med 61:831-840. Medline

Penfield W (1977) No man alone: a neurosurgeon's life. New York: Little Brown.

Penfield W, Boldfrey E (1937) Somatic motor and sensory representation in the cerebral cortex of man as studied by electrical stimulation. Brain 60 .

Penfield W, Evans J (1935) The frontal lobe in man: a clinical study of maximum removal. Brain 58:115-133. CrossRef

Penfield W, Milner B (1958) Memory deficit produced by bilateral lesions in the hippocampal zone. AMA Arch Neurol Psychiatry 79:475-497. CrossRef Medline

Penfield W, Perot P (1963) The brain's record of auditory and visual experience: a final summary and discussion. Brain 86:595-696. CrossRef Medline

Poo MM, Pignatelli M, Ryan TJ, Tonegawa S, Bonhoeffer T, Martin KC, Rudenko A, Tsai LH, Tsien RW, Fishell G, Mullins C, Gonçalves JT, Shtrahman M, Johnston ST, Gage FH, Dan Y, Long J, Buzsáki G, Stevens C (2016) What is memory? The present state of the engram. BMC Biol 14:40. CrossRef Medline

Port RL, Romano AG, Steinmetz JE, Mikhail AA, Patterson MM (1986) Retention and acquisition of classical trace conditioned responses by rabbits with hippocampal lesions. Behav Neurosci 100:745-752. CrossRef Medline
Ramirez S, Liu X, Lin PA, Suh J, Pignatelli M, Redondo RL, Ryan TJ, Tonegawa S (2013) Creating a false memory in the hippocampus. Science 341:387-391. CrossRef Medline

Ramirez S, Liu X, MacDonald CJ, Moffa A, Zhou J, Redondo RL, Tonegawa S (2015) Activating positive memory engrams suppresses depression-like behaviour. Nature 522:335-339. CrossRef Medline

Rashid AJ, Yan C, Mercaldo V, Hsiang HL, Park S, Cole CJ, De Cristofaro A, Yu J, Ramakrishnan C, Lee SY, Deisseroth K, Frankland PW, Josselyn SA (2016) Competition between engrams influences fear memory formation and recall. Science 353:383-387. CrossRef Medline

Redondo RL, Kim J, Arons AL, Ramirez S, Liu X, Tonegawa S (2014) Bidirectional switch of the valence associated with a hippocampal contextual memory engram. Nature 513:426-430. CrossRef Medline

Rilling M (1996) The mystery of the vanished citations: James McConnell's forgotten 1960s quest for planarian learning, a biochemical engram, and celebrity. Am Psychologist 51:589-598. CrossRef

Rogerson T, Jayaprakash B, Cai DJ, Sano Y, Lee YS, Zhou Y, Bekal P, Deisseroth K, Silva AJ (2016) Molecular and cellular mechanisms for trapping and activating emotional memories. PLoS One 11:e0161655. CrossRef Medline

Roy DS, Arons A, Mitchell TI, Pignatelli M, Ryan TJ, Tonegawa S (2016) Memory retrieval by activating engram cells in mouse models of early Alzheimer's disease. Nature 531:508-512. CrossRef Medline

Rugg MD, Vilberg KL (2013) Brain networks underlying episodic memory retrieval. Curr Opin Neurobiol 23:255-260. CrossRef Medline

Russell B (1922) The analysis of mind. New York: Allen, Unwin.

Ryan TJ, Roy DS, Pignatelli M, Arons A, Tonegawa S (2015) Memory: engram cells retain memory under retrograde amnesia. Science 348:10071013. CrossRef Medline

Sakaguchi M, Hayashi Y (2012) Catching the engram: strategies to examine the memory trace. Mol Brain 5:32. CrossRef Medline

Schacter DL (1982) Stranger behind the engram: theories of memory and the psychology. Hillsdale, NJ: Erlbaum.

Schacter DL (2001) Forgotten ideas, neglected pioneers: Richard Semon and the story of memory. Abingdon, United Kingdom: Psychology.

Schacter DL, Eich JE, Tulving E (1978) Richard Semon's theory of memory. J Verbal Learn Verbal Behav 17:721-743. CrossRef

Scoville WB, Milner B (1957) Loss of recent memory after bilateral hippocampal lesions. J Neurochem 20:11-21. CrossRef Medline

Semon R (1921) The mneme. London: Allen, Unwin.

Semon RW (1923) Mnemic psychology. London: Allen, Unwin.

Shomrat T, Levin M (2013) An automated training paradigm reveals longterm memory in planarians and its persistence through head regeneration. J Exp Biol 216:3799-3810. CrossRef Medline

Smalheiser NR, Manev H, Costa E (2001) RNAi and brain function: was McConnell on the right track? Trends Neurosci 24:216-218. CrossRef Medline

Solomon PR, Vander Schaaf ER, Thompson RF, Weisz DJ (1986) Hippocampus and trace conditioning of the rabbit's classically conditioned nictitating membrane response. Behav Neurosci 100:729-744. CrossRef Medline

Squire LR (1987) Memory and brain. New York: Oxford UP.

Squire LR, Alvarez P (1995) Retrograde amnesia and memory consolidation: a neurobiological perspective. Curr Opin Neurobiol 5:169-177. CrossRef Medline

Steinmetz JE, Lavond DG, Ivkovich D, Logan CG, Thompson RF (1992) Disruption of classical eyelid conditioning after cerebellar lesions: damage to a memory trace system or a simple performance deficit? J Neurosci 12:4403-4426. Medline

Stern L (2013) Psychological hijinks. APA Monitor 44:24-25.

Tanaka KZ, Pevzner A, Hamidi AB, Nakazawa Y, Graham J, Wiltgen BJ (2014) Cortical representations are reinstated by the hippocampus during memory retrieval. Neuron 84:347-354. CrossRef Medline

Thompson R, McConnell J (1955) Classical conditioning in the planarian, Dugesia dorotocephala. J Comp Physiol Psychol 48:65-68. CrossRef Medline

Thompson RF (1998) Richard F. Thompson. In: The history of neuroscience in autobiography (Squire LR, ed), pp 520-550. San Diego: Academic.

Tonegawa S, Liu X, Ramirez S, Redondo R (2015a) Memory engram cells have come of age. Neuron 87:918-931. CrossRef Medline

Tonegawa S, Pignatelli M, Roy DS, Ryan TJ (2015b) Memory engram 
storage and retrieval. Curr Opin Neurobiol 35:101-109. CrossRef Medline

Tulving E (1982) Synergistic ecphory in recall and recognition. Can J Psychol 36:130-147. CrossRef

Welsh JP, Harvey JA (1991) Pavlovian conditioning in the rabbit during inactivation of the interpositus nucleus. J Physiol 444:459-480. CrossRef Medline

Wheeler AL, Teixeira CM, Wang AH, Xiong X, Kovacevic N, Lerch JP, McIntosh AR, Parkinson J, Frankland PW (2013) Identification of a functional connectome for long-term fear memory in mice. PLoS Comput Biol 9:e1002853. CrossRef Medline

Wilson MA, McNaughton BL (1994) Reactivation of hippocampal ensemble memories during sleep. Science 265:676-679. CrossRef Medline

Winocur G, Moscovitch M, Bontempi B (2010) Memory formation and long-term retention in humans and animals: convergence towards a transformation account of hippocampal-neocortical interactions. Neuropsychologia 48:2339-2356. CrossRef Medline

Yeo CH, Hardiman MJ, Glickstein M (1985) Classical conditioning of the nictitating membrane response of the rabbit: II. Lesions of the cerebellar cortex. Exp Brain Res 60:99-113. CrossRef Medline

Yiu AP, Mercaldo V, Yan C, Richards B, Rashid AJ, Hsiang HL, Pressey J, Mahadevan V, Tran MM, Kushner SA, Woodin MA, Frankland PW, Josselyn SA (2014) Neurons are recruited to a memory trace based on relative neuronal excitability immediately before training. Neuron 83 : 722-735. CrossRef Medline

Yoshii T, Hosokawa H, Matsuo N (2016) Pharmacogenetic reactivation of the original engram evokes an extinguished fear memory. Neuropharmacology 113:1-9. CrossRef Medline 